\title{
Influence of CTL Approach To Improve Critical Thinking Skills and Social Study Learning Outcomes In Primary Schools
}

\author{
Kuspina Pandu Winata, Rusijono, Ketut Prasetyo, Waspodo Tjipto Subroto \\ Universitas Negeri Surabaya \\ Surabaya, Indonesia \\ Vinawinata_87@yahoo.com
}

\begin{abstract}
The research aims to examine the effects of the application of contextual teaching and learning (CTL) approach to increase critical thinking skills and student learning outcomes in primary school. This research used Quasi-Experimental Research using nonequivalent group design. The data were obtained from several instruments, i.e. a test of social studies learning outcomes in form of multiple choice as many as 20 questions and critical thinking study question in a form of essay as many as 6 questions. The data was analyzed by using t-test. The results showed: (1) learning result of social studies using CTL learning approach is higher than that of social studies using conventional learning approach with average score of CTL approach 82.00, and the average conventional approach 72.50 (2) the result of social studies with high critical thinking score is 80.00 and low critical thinking score is 70.67. Based on the data analysis it can be concluded that the CTL approach can increase critical thinking skills.
\end{abstract}

Keyword-Contextual Teaching and Learning, Critical Thinking, Learning Outcomes

\section{INTRODUCTION}

Childhood in elementary school is the most effective stage to develop various potential [1]. At this time the pattern of growth and development i.e. physical, social, emotional and cognitive development has developed optimally [2]. Piaget splits develops into level 4: sense motor, preoperative, concrete operational and formal operations" [3]. Efforts to train children at the age of 7-12 years at a concrete operational time are children developing concepts by using concrete objects [4]. This means that learning at the primary school level should be applied to the events related to the learner's environment. Learning the meaning of the process of linking new knowledge in the same concept in cognitive ability. Meaningfulness in various learning, proper learning will bring students to an impressive experience. According to the theory of Meaningful Learning from Ausabel, each subject studied by the student must be alone. The learning process is able to solve the problem independently by using the experience and knowledge possessed by pasture learners will produce more meaningful knowledge which can provide a concrete experience used by learners [5].

From the observation of social studies learning the process on the material of buying and selling activity is still dominated by lecture method and assignment. Also found facts in the process of teaching and learning in class III in SDN P1 01 which takes place both teachers and students include (1) delivering the material in the learning process is done abstractly; (2) untrained learners to solve problems critically; (3) the presenter of the material presented is less attention to the student's real life; (4) student learning outcomes are low on the material of buying and selling activities. Of the several problems are caused by the students' activities in learning to teach more dominant listening so less able to associate the concept of learning with student experience and make learning meaningless.

It can be seen from the achievement of the observation and evaluation of learning process of social studies on the material of sale and purchase activity of the third-grade students of the second semester of academic year 2017/2018 is still below the minimum completeness Criteria (KKM) established by the school that is 70 . Learning result data is shown with the lowest score of 60 and the highest score of 85 , with an average grade of 65.25 for daily test scores. In addition, based on the preliminary study of the critical thinking test of students conducted in SDN Pajaran 01 on the sample of class III of the material of buying and selling activities there are $30 \%$ of students who are able to think critically, it can be known from all third grade students $30 \%$ of students who are able to answer about the critical thinking skills test. It shows that the critical thinking skills of learners in understanding the material of buying and selling activities are still low. By analyzing the data of learning outcomes and the implementation of learning activities need to be improved the quality, one of them is by using the application of learning approach that emphasizes the activeness of the learners to develop the potential to the maximum, so students can think critically and creatively. "Critical thinking skills are rational thinking (sensible) and focus on the beliefs and decisions that have been made" [6]. 
Critical thinking is the mode of thinking, about any subject, content or problem in which the thinker improves the quality of their thinking by ski fully taking the charge of the structures inherent in thinking and imposing intellectual standards upon them[4]. This means that critical thinking is the model of thinking about a subject, content or problem in which a thinker can improve the quality of their thinking by taking over the existing structures of thought and applying its intellectual standard. Students who are equipped with critical thinking skills are able to assess the opinions of a right and wrong person based on scientific truth and knowledge so that students can solve problems and face challenges and daily demands effectively without any hesitation.

Based on the above description, students are expected to have critical thinking skills to the maximum so as to improve learning outcomes. Learning outcomes are something that students gain from experiences or exercises that are followed during learning activities in the form of cognitive, affective and psychomotor skills. By looking at some of the problems already exist in the end researchers and teachers together to discuss and find a way out to solve the problem. In the end, the researcher is interested to develop the student's way of thinking which can improve the students 'learning outcomes both cognitively related to the students' knowledge or memory, the effective relating to the students 'attitude during the learning, the student psychomotor which is related to the students' motor skills.

CTL approach provides an opportunity for students to be able to think by realizing the real world with the material of buying and selling activities delivered by teachers in learning. Buying and selling activities are usually done by students. What if the students already have an understanding of relating the lessons to the real world then they will easily understand the lessons that teachers provide so as to make learning more meaningful. Therefore, the task of a teacher is to connect the concepts of lessons taught to the real world of students so that students can relate between the knowledge that has been owned by the application in everyday life.

"CTL approach is a learning concept that links the teaching materials with the experience and knowledge possessed by learners so that learners are able to apply that knowledge in the life of society [7].. CTL is a system that helps students to learn to see meaning" material, and see meaning schoolwork when the student learns with student's experience ". This means that the CTL approach is a guidance system based on a philosophy in which learners are able to see meaning in an academic material and be able to do schoolwork as learners can connect new information with the knowledge that learners have.

The CTL approach centers on students who can generate critical and creative thinking habits. Dig the potential possessed by students gained from experience experienced to associate with the knowledge learned. In accordance with the theory of constructivism that to construct knowledge of students does not come from the empty mind, but students must have the knowledge to be known which is called as early knowledge. In this case there is a goal to be achieved in the CTL approach is to provide motivation to students to be able to understand the content of the material learned learners by connecting the subject matter to everyday experience, so that from the skills and knowledge obtained can be applied to other problems [8]. This means that the goal of the CTL approach is meaningful learning for students. Learning activities run naturally with the way students experience themselves so that students can be active and critical thinking.

Critical thinking can inspire students to find the truth in the midst of everyday events. In addition, the students do not take for granted the events they see or experience but the students will dig into more complete information and think how to understand, do, compile, assess and overcome them. The results of this study indicate that the CTL approach not only improves the mastery of the concept but the process skills that can relate the experience possessed by students with the concepts obtained. Based on the theory of learning, existing problems and relevant research, the researcher conducts research as an effort to increase the ability of critical thinking and learning outcomes in the subjects of IPS material buying and selling activities with the title "The Influence of Contextual Teaching and Learning Approach to Critical Thinking Skills and Hail Learning social studies Material of Sale and Sell Activities of Class III Primary School ".

\section{METHOD}

A research method that is used by the researcher is "Quasi-Experimental Method" with research design as the base of research implementation. It is to distinguish the influence of learning model of CTL and influence of model of the conventional result of a Social study to increase students outcomes and critical thinking where III-A as an experiment class and III B as a control class with the total number is 22 people, the sample is all students of class III. The instruments used are observation sheets and tests. Data analysis technique uses mean Whitney / $\mathrm{u}$ test, and hypothesis technique using t-test.

\section{RESULTS AND DISCUSSION}

TABLE 6. T-TEST

\begin{tabular}{|c|c|c|c|c|c|}
\hline & Class & $\mathrm{N}$ & Mean & $\begin{array}{c}\text { Std. } \\
\text { Deviation }\end{array}$ & $\begin{array}{c}\text { Std. Error } \\
\text { Mean }\end{array}$ \\
\hline \multirow{2}{*}{$\begin{array}{l}\text { Learning } \\
\text { out comes }\end{array}$} & $\begin{array}{c}\text { Pre-test } \\
\text { experiment class } \\
(\mathrm{CTL})\end{array}$ & 10 & 71.00 & 11.972 & 3.786 \\
\hline & $\begin{array}{l}\text { Pre-test control } \\
\text { class }\end{array}$ & 12 & 70.00 & 10.225 & 2.952 \\
\hline
\end{tabular}

Based on t-test results it can be seen that the average value of pretest from the experimental group is 71.00 and the mean pre-test in the control group 70.00. Furthermore, to 
know the ability and analysis can be tested by independent sample test shown in the table below.

Table 7. Independent Samples Test

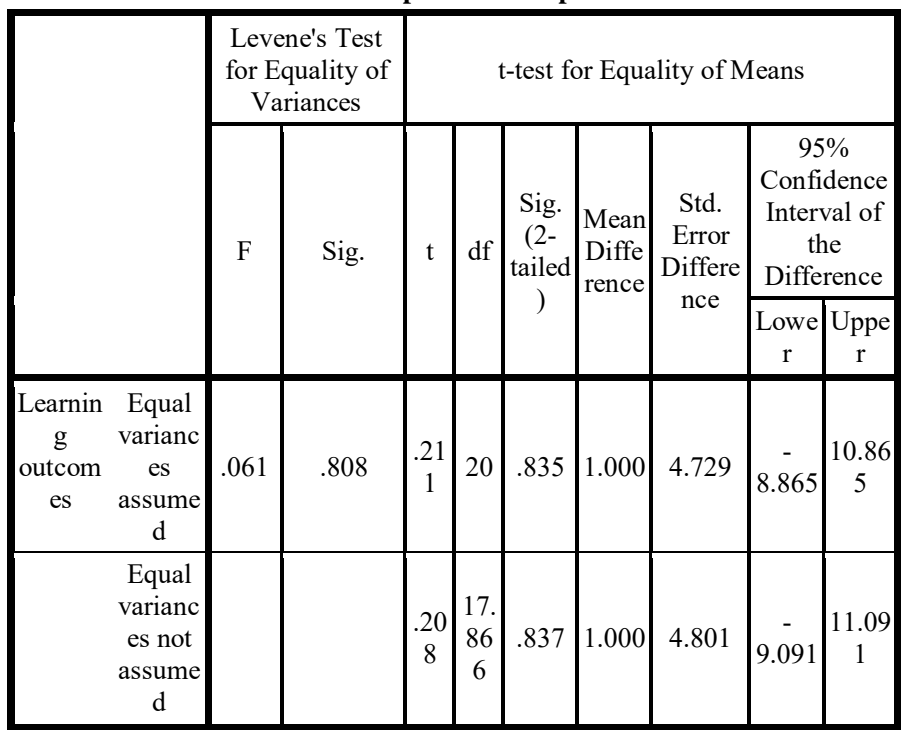

Based on test results from SPSS 24 for windows, it is known that the Sig. (2-tailed) of $0.835>0.05$, because the Sig. (2-tailed) of 0.835 is greater 0.05 it can be concluded that the initial capability of learning outcomes in the experimental group and the control group did not have a significant difference

\begin{tabular}{|cc|c|c|c|c|}
\hline & Class & $\mathrm{N}$ & Mean & $\begin{array}{c}\text { Std. } \\
\text { Deviation }\end{array}$ & $\begin{array}{c}\text { Std. Error } \\
\text { Mean }\end{array}$ \\
\hline Learning & $\begin{array}{c}\text { Post-test } \\
\text { Experimnent } \\
\text { class (CTL) }\end{array}$ & 10 & 82.00 & 8.233 & 2,603 \\
& $\begin{array}{c}\text { Post-test control } \\
\text { class }\end{array}$ & 12 & 72.50 & 8.394 & 2.423
\end{tabular}

Based on t-test results it can be seen that the average value of post-test from the experimental group is 82.00 and the mean pre-test in the control group 72.50. Furthermore, to know the ability and analysis can be tested by independent sample test shown in the table below.

TABEL 9. INDEPENDENT SAMPLES TEST (LEARNING OUTCOMES)

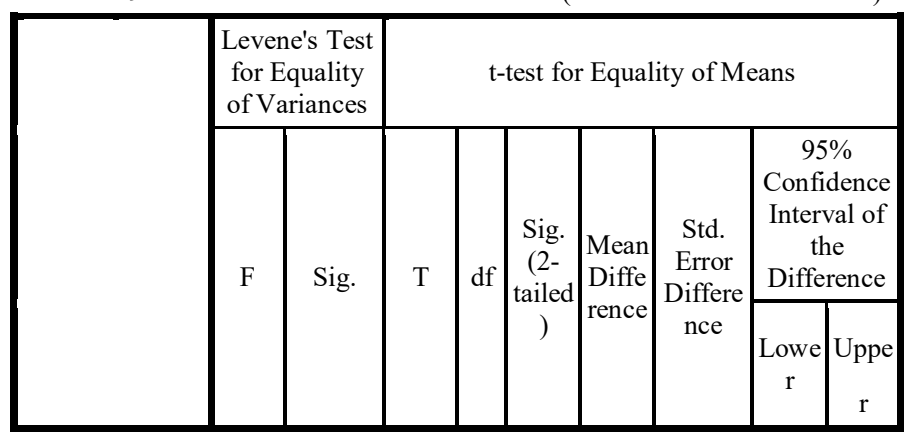

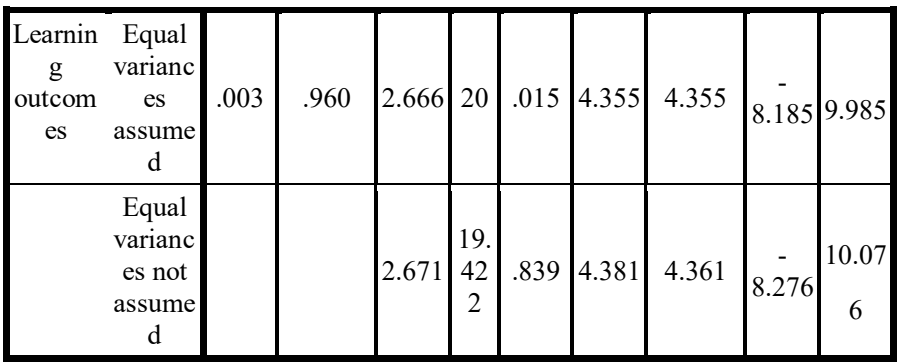

Based on test results from SPSS 24 for windows, it is known that the Sig. (2-tailed) of $0.018>0.05$, because the Sig. (2-tailed) of 0.015 is greater 0.05 it can be concluded that the initial capability of learning outcomes in the experimental group and the control group did not have a significant difference

TABEL 10. T-TEST CRITICAL THINKING SKILLS

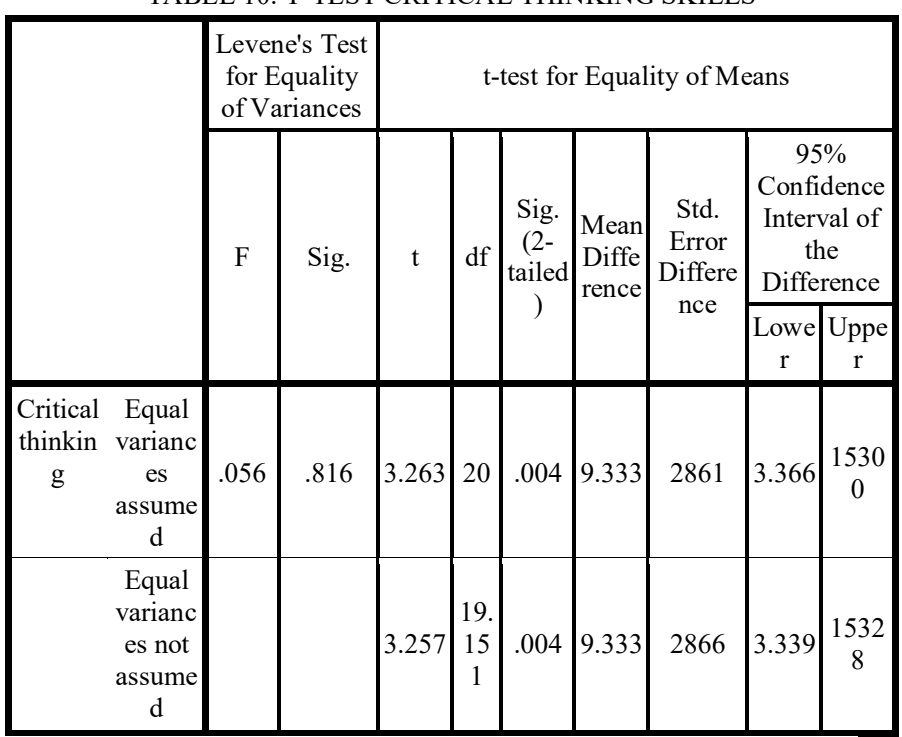

Based on test results from SPSS 24 for windows, it is known that the Sig. (2-tailed) of $0.004>0.05$, because the Sig. (2-tailed) of 0.004 is greater 0.05 it can be concluded that the initial capability of learning outcomes in the experimental group and the control group did not have a significant difference.

\section{DISCUSSION}

CTL is a method that influences Learning outcomes in the achievement of educational goals in students who follow the learning process to increase critical thinking skills [9]. Learning outcomes are the realization of the achievement of educational goals so that the measure of learning outcome depends on the purpose of education. Learning outcomes need to be evaluated as a learning process has been achieved and the teaching-learning process has been effective in achieving learning outcomes [10].

\section{CONCLUSION}

The first hypothesis is $\mathrm{H} 0: \mu \mathrm{A} 1=\mu \mathrm{A} 2$ : no effect of CTL learning model on student learning outcomes Ha: $\mu \mathrm{A} 1 \neq$ $\mu \mathrm{A} 2$ : there is an influence of CTL approach on student learning outcomes. Based on the results of t-test on table 9 
obtained value of learning outcomes with significance 2 tailed is 0.015 because sig 2 tailed less than 0.05 can be concluded that the hypothesis test results reject $\mathrm{H} 0$ or receive $\mathrm{Ha}$ in the level of 5\% alpha. This shows that there is an influence of CTL learning model on student learning outcomes. Because the average of learning outcomes of experiment class by using CTL approach is higher than that taught with conventional learning. it can be concluded that the CTL approach gives better influence to student learning outcome than conventional.

Second hypothesis $\mathrm{H} 0: \mu \mathrm{B} 1=\mu \mathrm{B} 2$ : there is no effect of critical thinking on learning outcomes of students' Social Studies learning $\mathrm{H} 0: \mu \mathrm{B} 1 \neq \mu \mathrm{B} 2$ : there is an effect of critical thinking of students' Social Studies learning Based on the results of t-test in Table 10 obtained the significance value of critical thinking learning by 0.004 because sig 0.004 $<0.05$ then the hypothesis test results reject $\mathrm{H} 0$ or accept the $\mathrm{Ha}$ in the level of 5\% alpha. This shows that there is the influence of critical thinking learning on student learning result of Social Studies. Because mean of the result of student learning which has high critical thinking in experiment class than control class that using conventional, hence can be concluded high critical thinking give better influence to result of experiment class that uses CTL approach than control class that uses the conventional method.

\section{REFERENCES}

[1] J.S. Eccles, C. Midgley, A. Wigfield, C.M. Buchanan, D. Reuman, C. Flanagan, D. Mac Iver, Development During Adolescence: The Impact of Stage-Environment Fit on Young Adolescents Experience in Schools and in Families, American Psychologist, 48 (2):90, 1993.

[2] Jean Piaget, Cognitive Development in Children: Piaget Development and Learning, Journal of Research in Science Teaching, 2(3): 176-186, 1964.

[3] J. Montangero, D. Maurice-Naville, Piaget or the Advance of Knowledge: an Overview and Glossary, Psychology Press, 2013.

[4] Ratnawilis Dahar, Teori-teori Belajar dan Pembelajaran, Bandung: Erlangga, 2011.

[5] R.H. Ennis, The Nature of Critical Thinking: An Outline of Critical Thinking Disposition and Abilities, University of Illinoin, 2011.

[6] Alec Fisher, Critical Thinking an Introduction, New York: Cambridge University Press, 2015.

[7] B. Elaine Johnson, Contextual Teaching and Learning, Bandung: Kaifa, 2012.

[8] Abdul Majid, Perencanaan Pembelajaran Mengembangkan Standar Kompetensi Guru, Bandung: Remaja Rosda Karya, 2012.

[9] P. Kimmel, Framework for Incorporating Critical Thinking Into Accounting Education, Journal of Accounting Education, 13(3):299$318,1995$.

[10]J. Biggs, What The Student Does: Teaching for Enhanced Learning, Higher Education Research \& Development, 18(1): 57-75, 1999. 